\title{
Ticks in wild animals at a resort and the first documentation of Amblyomma sculptum infesting Emu (Dromaius novaehollandiae)
}

Carrapatos em animais selvagens em um resort e o primeiro registro de Amblyomma sculptum infestando Emu (Dromaius novaehollandiae)

Izabela Mesquita Araújo'; Paulo Cesar Magalhães-Matos ${ }^{1}$; Matheus Dias Cordeiro'; Adlilton Pacheco ${ }^{1}$; Bruno Silva Rocha ${ }^{2}$; Luis Felipe Barbosa Braga Feitoza ${ }^{1}$; Argemiro Sanavria ${ }^{1}$; Adivaldo Henrique Fonseca ${ }^{1 *}$ (E)

\author{
${ }^{1}$ Programa de Pós-graduação em Ciências Veterinárias, Universidade Federal Rural do Rio de Janeiro - UFRRJ, Seropédica, RJ, Brasil \\ ${ }^{2}$ Portobello Resort, Mangaratiba, RJ, Brasil
}

Received August 23, 2018

Accepted October 10, 2018

\begin{abstract}
The study aimed to identify species of ticks present in the environment and among captive animals, in Mangaratiba, Rio de Janeiro, Brazil. Ticks were isolated from captive animals by manual examination and free-living ticks in the environment were captured using the flannel drag technique. A total of 91 ticks were obtained ( 51 adults, 25 nymphs and 15 larvae). The specimens were identified morphologically as Amblyomma sp., Amblyomma dubitatum, Amblyomma ovale and Amblyomma sculptum, and were distributed among five species of native mammals and an exotic bird. This study also reports the first case of infestation of the Australian emu (Dromaius novaehollandiae) by A. sculptum.
\end{abstract}

Keywords: Ticks, Amblyomma, wild animal, Rio de Janeiro, Brazil.

\section{Resumo}

O estudo teve como objetivo identificar espécies de carrapatos presentes no ambiente e entre animais de cativeiro em Mangaratiba, Rio de Janeiro, Brasil. Os carrapatos foram removidos manualmente de animais de cativeiro e no ambiente usando a técnica de arrasto em flanela. Um total de 91 carrapatos foram capturados (51 adultos, 25 ninfas e 15 larvas). Os espécimes foram identificados morfologicamente como Amblyomma sp., Amblyomma dubitatum, Amblyomma ovale e Amblyomma sculptum, e foram distribuídos entre cinco espécies de mamíferos nativos e uma ave exótica. Este estudo também relata o primeiro caso de infestação do emu australiano (Dromaius novaehollandiae) por A. sculptum.

Palavras-chave: Carrapatos, Amblyomma, animais selvagens, Rio de Janeiro, Brasil.

Ticks are haematophagous ectoparasites with a cosmopolitan distribution and a wide variety of species (GUGLIELMONE et al., 2014). In Brazil, most species of ticks belong to the genus Amblyomma (DANTAS-TORRES et al., 2012), which parasitize a great diversity of hosts. Humans may also play host to these ticks when coming into contact with their natural habitat and hosts (BARROS-BATTESTI et al., 2006).

In Brazil, recent studies have demonstrated the importance of knowing the species of ticks on captive animals in public and private conservation units (GONZALEZ et al., 2017; MAGALHÁES-MATOS et al., 2017; NASCIMENTO et al., 2017).

\footnotetext{
*Corresponding author: Adivaldo Henrique Fonseca. Departamento de Epidemiologia e Saúde Pública, Instituto de Veterinária, Universidade Federal Rural do Rio de Janeiro - UFRRJ, Campus de Seropédica, BR 465, Km 7, Bairro Ecologia, CEP 23891-000, Seropédica, RJ, Brasil. e-mail: adivaldofonseca@yahoo.com
}

Therefore, this study aimed to identify tick species occurring in the environment and among captive animals at a resort and safari in the municipality of Mangaratiba, Rio de Janeiro.

The study was carried out between September 2016 and February 2017 at a Porto Bello safari belonging to a Resort in Mangaratiba, Rio de Janeiro state, Brazil (2254'58.135”S, 444'23.046”W). This safari has an area of $300.000 \mathrm{~m}^{2}$ and houses about 500 animals of the South American, European and African fauna, which coexist in the same environment. Among the species that inhabit the safari are zebras (Equus burchellii Linnaeus, 1758), camels (Camelus dromedaries Linnaeus, 1758), dromedaries (Camelus bactrianus Linnaeus, 1758), llamas (Lama glama Linnaeus, 1758), deer (Rusa unicolor Kerr, 1792), capybaras (Hydrochoerus hydrochaeris Linnaeus, 1766), tapirs (Tapirus terrestris Linnaeus, 1758), peccaries (Tayassu tajacu Linnaeus, 1758), and a variety of wild birds such as macaws (Ara chloropterus Gray, 1859), emus (Dromaius novaehollandiae Latham, 1790) and ostriches (Struthio camelus Linnaeus, 1758). 
During the study period, visits were made to the safari with the objective of collecting ticks from the animals and searching the environment by dragging white flannel over the vegetation, as described by Oliveira et al. (2000).

Immediately after collection, all ticks were packed in polypropylene tubes containing RNAlater ${ }^{\circledR}$ solution. Thereafter, they were transported to the laboratory. Taxonomic identification was performed based on morphology using dichotomic keys specific for ixodid ticks, the key proposed by Martins et al. (2010) for nymphs and the key modified by Guimarães et al. (2001) in Barros-Battesti et al. (2006) and Nava et al. (2014) for adults.

In total, 91 ticks of the genus Amblyomma were obtained, 51 adults, 25 nymphs and 15 larvae. The identities of tick species and their respective hosts are shown in Table 1.

Amblyomma sculptum Berlese, 1888 was captured in the environment and was also found parasitizing capybara (Hydrochoerus hydrochaeris Linnaeus, 1766), tapirs (Tapirus terrestris Linnaeus, 1758), peccary (Tayassu tajacu Linnaeus, 1758) and an emu, Dromaius novaehollandiae Latham, 1790 (Table 1, Figure 1). According to Guimarães et al. (2001), it is common to find $A$. sculptum in large and medium-sized mammals. The ticks are mainly found on capybaras and tapirs, as they play a fundamental role in the lifecycle of the tick, serving as the main hosts for all parasitic stages.

This is the first record of $A$. sculptum from an emu, a large bird that is not capable of flying, native to Australia and present over almost the entire continent, especially in semi-arid regions (THOMPSON, 2001). To date, there is limited knowledge regarding the species of ticks that commonly parasitize emus, with only a recent study reporting the parasitism by Ixodes cornuatus Roberts, 1960 of a captive emu at the Healesville sanctuary, Australia (KWAK

Table 1. Ticks captured in vegetation and collected in wild animals kept in captivity on a safari, in the municipality of Mangaratiba, Rio de Janeiro, Brazil.

\begin{tabular}{|c|c|}
\hline Hosts (n) & $\begin{array}{c}\text { Numbers, stages and species of } \\
\text { ticks }\end{array}$ \\
\hline \multicolumn{2}{|l|}{ Mammalia } \\
\hline \multicolumn{2}{|l|}{ Order Perissodactyla } \\
\hline Tapirus terrestis (2) & $5 \mathrm{M}, 1 \mathrm{~F}, 1 \mathrm{~N}$ A. sculptum \\
\hline \multicolumn{2}{|l|}{ Order Artiodactyla } \\
\hline Tayassu tajacu (1) & 1M A. sculptum \\
\hline \multicolumn{2}{|l|}{ Order Rodentia } \\
\hline Hydrochoerus hydrochaeris (1) & $\begin{array}{l}\text { 1F A. ovale; } 5 \mathrm{~F} \text { A. dubitatum; 2F, } \\
\text { 13M, 1N A. sculptum }\end{array}$ \\
\hline H. hydrochaeris (1) & 20M, 3F A. dubitatum; $1 \mathrm{~N}$ A. incisum \\
\hline \multicolumn{2}{|l|}{ Aves } \\
\hline \multicolumn{2}{|l|}{ Order Casuariiformes } \\
\hline Dromaius novaehollandiae (1) & $8 \mathrm{~N}$ A. sculptum \\
\hline \multicolumn{2}{|l|}{ Reptilia } \\
\hline \multicolumn{2}{|l|}{ Order Testudinata } \\
\hline Chelonoidis spp. (12) & 0 \\
\hline Questing Ticks* & 14N A. sculptum; 15L Amblyomma sp. \\
\hline $\mathrm{L}=$ larvae; $\mathrm{N}=$ nynphs; $\mathrm{A}=$ adults; & \\
\hline $\begin{array}{l}{ }^{*} \text { Free-living ticks captured throug } \\
\text { over vegetation. }\end{array}$ & the technique of dragging a white flan \\
\hline
\end{tabular}

\& MADDEN, 2017). In the present study, eight semi-engorged nymphs of $A$. sculptum were found fixed to the temporal region of the head and proximal part of the neck of captive animals at a safari in Rio de Janeiro, Brazil (Table 1, Figure 1). Of these nymphs, two were deposited at the collection of Wingless Vector Arthropods of Importance in the Health of Communities of the Oswaldo Cruz Institute (CAVAISC - FIOCruz), in Rio de Janeiro, with deposit numbers CAVAISC-IXO 3296.

Ticks of the species Amblyomma dubitatum Neumann, 1899, Amblyomma ovale Koch, 1844 and Amblyomma incisum Neumann, 1906 were found in the inspected capybara (Table 1). This large rodent has previously been described as the main host for all parasitic stages of $A$. dubitatum (NAVA et al., 2010). However, $A$. ovale is most commonly recorded in wild and domestic carnivores (GUGLIELMONE et al., 2003; LABRUNA et al., 2005a; MAGALHÁES-MATOS et al., 2017), with small rodents as hosts during the immature stages (GUGLIELMONE et al., 2003). Amblyomma incisum primarily parasitizes the tapir in adulthood (LABRUNA et al., 2005b) and little is known about hosts for the immature stages (GUIMARÁES et al., 2001; SZABÓ et al., 2009). In the present study, although no specimen of $A$. incisum was found in the tapirs, the animals sharing an enclosure may have facilitated the infestation of capybaras by a nymph of this species of tick. No ticks were found in the inspected Chelonoidis spp. (Table 1).

Therefore, it is important to perform acarological surveys in captive animals, especially in places where humans are common (such as safaris and zoos) since many species of ticks therein are vectors of pathogens that cause human diseases. In this study, three species of ticks that are of great importance for public health were identified, namely $A$. sculptum, $A$. dubitatum and $A$. ovale, which are responsible for the transmission of Rickettsia bacteria that cause spotted fever (SZABÓ et al., 2013).

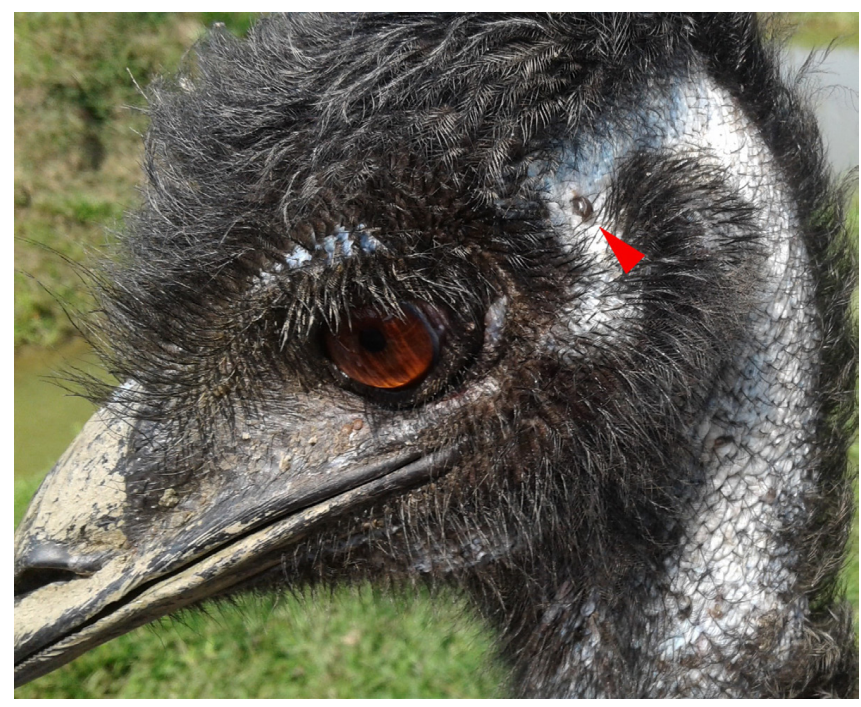

Figure 1. An emu (Dromaius novachollandiae) infested by a nymph of Amblyomma sculptum in the left temporal region of the head (arrow). 


\section{Acknowledgements}

We would like to express our gratitude to the Fundação de Amparo à Pesquisa do Rio de Janeiro - FAPERJ (A.H.F., grant number E 26/201.144/2014) and Conselho Nacional de Desenvolvimento Científico e Tecnológico - CNPq) (A.H.F. 305480/2013-8), for their financial assistence.

\section{References}

Barros-Battesti DM, Arzua M, Bechara GH. Carrapatos de importância médico-veterinária da região neotropical: um guia ilustrado para identificação de espécies. $1^{\text {a }}$ ed. São Paulo: Vox/ICTTD-3/Butantan; 2006.

Dantas-Torres F, Chomel BB, Otranto D. Ticks and tick-borne diseases: a One Health perspective. Trends Parasitol 2012; 28(10): 437-446. http:// dx.doi.org/10.1016/j.pt.2012.07.003. PMid:22902521.

Gonzalez IHL, Labruna MB, Chagas CRF, Salgado PAB, Monticelli C, Morais LH, et al. Ticks infesting captive and free-roaming wild animal species at the São Paulo Zoo, São Paulo, Brazil. Rev Bras Parasitol Vet 2017; 26(4): 496-499. http://dx.doi.org/10.1590/s1984-29612017036. PMid:28700000.

Guglielmone AA, Estrada-Peña A, Mangold AJ, Barros-Battesti DM, Labruna MB, Martins JR, et al. Amblyomma aureolatum (Pallas, 1772) and Amblyomma ovale Koch, 1844 (Acari: Ixodidae): hosts, distribution and 16S rDNA sequences. Vet Parasitol 2003; 113(3-4): 273-288. http:// dx.doi.org/10.1016/S0304-4017(03)00083-9. PMid:12719142.

Guglielmone AA, Robbins RG, Apanaskevich DA, Petney TN, Estrada-Peña A, Horak IG. The hard ticks of the world (Acari: Ixodida: Ixodidae). $1^{\mathrm{a}} \mathrm{ed}$. London: Springer; 2014. http://dx.doi.org/10.1007/978-94-007-7497-1.

Guimarães JH, Battesti DMB, Tucci EC. Ectoparasitos de importância veterinária. $1^{a}$ ed. São Paulo: Plêiade/Fapesp; 2001.

Kwak ML, Madden C. The first record of infestation by a native tick (Acari: Ixodidae) on the Australian emu (Dromaius novaehollandiae) and a review of tick paralysis in Australian birds. Exp Appl Acarol 2017; 73(1): 103-107. http://dx.doi.org/10.1007/s10493-017-0168-0. PMid:28849543.

Labruna MB, Jorge RSP, Sana DA, Jácomo ATA, Kashivakura CK, Furtado MM, et al. Ticks (Acari: Ixodida) on wild carnivores in Brazil. Exp Appl Acarol 2005a; 36(1): 149-163. http://dx.doi.org/10.1007/ s10493-005-2563-1. PMid:16082932.

Labruna MB, Keirans JE, Camargo LMA, Ribeiro AF, Soares RM, Camargo EP. Amblyomma latepuncatatum, a valid tick species (Acari: Ixodidae) long misidentified with both and Amblyomma scalpturatum. J
Parasitol 2005b; 91(3): 527-541. http://dx.doi.org/10.1645/GE-446R. PMid:16108543.

Magalhães-Matos PC, Moraes MFD, Valim JRA, Castro GNS, Santos PN, Manier BSML, et al. Ticks (Acari: Ixodidae) and lice (Phthiraptera: Trichodectidae) infesting free-living coatis (Nasua nasua Linnaeus, 1766) with sylvatic and synanthropic habits in the Atlantic rainforest of Southern Brazil. Syst Appl Acarol 2017; 22(6): 779-784. http://dx.doi. org/10.11158/saa.22.6.3.

Martins TF, Onofrio VC, Barros-Battesti DM, Labruna MB. Nymphs of the genus Amblyomma (Acari: Ixodidae) of Brazil: descriptions, redescriptions, and identification key. Ticks Tick Borne Dis 2010; 1(2): 75-99. http://dx.doi.org/10.1016/j.ttbdis.2010.03.002. PMid:21771514.

Nascimento KKG, Veríssimo SMM, Raia VA, Guimarães RCS, Seade GCC, Azevedo ACP, et al. Tick fauna of wild animals received and attended at the Santarém Zoological Park, western Pará State, Brazil. Cienc Rural 2017; 47(10). http://dx.doi.org/10.1590/0103-8478cr20170159.

Nava S, Beati L, Labruna MB, Cáceres AG, Mangold AJ, Guglielmone AA. Reassessment of the taxonomic status of Amblyomma cajennense (Fabricius, 1787) with the description of three new species, Amblyomma tonelliae n. sp., Amblyomma interandinum n. sp. and Amblyomma patinoi n. sp., and reinstatement of Amblyomma mixtum Koch, 1844, and Amblyomma sculptum Berlese, 1888 (Ixodida: Ixodidae). Ticks Tick Borne Dis 2014; 5(3): 252-276. http://dx.doi.org/10.1016/j.ttbdis.2013.11.004. PMid:24556273.

Nava S, Venzal JM, Labruna MB, Mastropaolo M, González EM, Mangold AJ, et al. Hosts, distribution and genetic divergence (16S rDNA) of Amblyomma dubitatum (Acari: Ixodidae). Exp Appl Acarol 2010; 51(4): 335-351. http://dx.doi.org/10.1007/s10493-009-9331-6. PMid:20084537.

Oliveira PR, Borges LMF, Lopes CML, Leite RC. Population dynamics of the free-living stages of Amblyomma cajennense (Fabricius, 1787) (Acari: Ixodidae) on pastures of Pedro Leopoldo, Minas Gerais State, Brazil. Vet Parasitol 2000; 92(4): 295-301. http://dx.doi.org/10.1016/ S0304-4017(00)00322-8. PMid:10996741.

Szabó MP, Pereira LF, Castro MB, Garcia MV, Sanches GS, Labruna MB. Biology and life cycle of Amblyomma incisum (Acari: Ixodidae). Exp Appl Acarol 2009; 48(3): 263-271. http://dx.doi.org/10.1007/s10493008-9234-y. PMid:19130270.

Szabó MPJ, Pinter A, Labruna MB. Ecology, biology and distribution of spotted-fever tick vectors in Brazil. Front Cell Infect Microbiol 2013; 3: 27. http://dx.doi.org/10.3389/fcimb.2013.00027. PMid:23875178.

Thompson RC. Raising Emus and Ostriches [online]. Beltsville: U.S. Department of Agriculture; 2001 [cited 2017 Oct 10 ]. Available from: https://pubs.nal.usda.gov/sites/pubs.nal.usda.gov/files/srb9706_0.htm 